線回折法により調べたとこる，䉓流饺率の但いBright $\mathrm{Ag}$, White $\mathrm{Ag}$ 極は $\mathrm{Ag}$ 結暃化もとつく回折環を攺上 えど現わさず，電流效率が良好な $\mathrm{NH}_{4} \mathrm{OH}$ 性 $\mathrm{Ag}_{2} \mathrm{SO}_{4}$ 谵

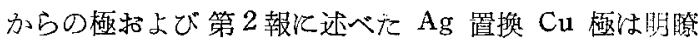
な面心立方 Ag 結晶による回折環を現わした。この絬 果心 Ag の結鼠性が BID の遑元力と密接な関連をすつ ことを示するのと考亮られる。

(3) $\mathrm{Zn}, \mathrm{Ni}, \mathrm{S}$ 化合物からなる Black $\mathrm{Ni}$ 極比婄い ては，BID 還元の電流效率が，前報に述べたように， 25〜73\% と大きく振れたが，ポーラ口的に再び検討し た結果，ポーラロ的にも実用的電解の結果と対応して BID の還元波在現わす極と現わさない極加あること存 認めた。

終りにのぞみ本研究の発表を許可された秋葉武定理事 長，終始ご指尊を頂いた所長中士晃博士に愿く御礼林し
シげ，また電子線回折测定について呿世話頂いた荒茾義 斫究員, 日本電子光学 (株) のかたがた, さら飞実験に 拁力された山田利明君に謝意を表する。

（昭 33-12-6 受理）

文 献

(1) 加藤二郎, 传久間正敏, 山田利明: 電化, 26，132（1958)

(2) 加藤二郎, 传久間正敏：同志，25，126(1957)

(3) 加岿二郎，传久間正敏，山田利明：同誌，25，331 (1957)

4) N.P. Fedot'ev, et a1: J. Applied Chem., 25, 322 (1952); C.A., 47,5276

5) Creighton and Koehler : "Electrochemistry" VoI.II, p. 145

(6) G.L. Brownell : Dissertation, The Ohio State Univ. (1953) P.15

（7）》最近刀物理化学実駼法"第 3 集 p.104（化学の領域增刊 15）

(8) 村上 透: "電鍍化学" p.221

(9) J.D. Hanawalt, et al : Ind. Eng. Chem., Anal. Ed., 10, 501 (1938)

\title{
インジウムとカドミウムのポーラログラフ的同時定量*
}

\section{Polarographic Method of Simultaneous Determination of Indium and Cadmium}

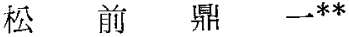

Teiichi Matsumae

\section{1. 緒訔}

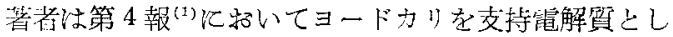

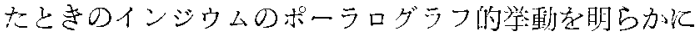

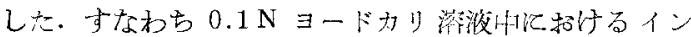

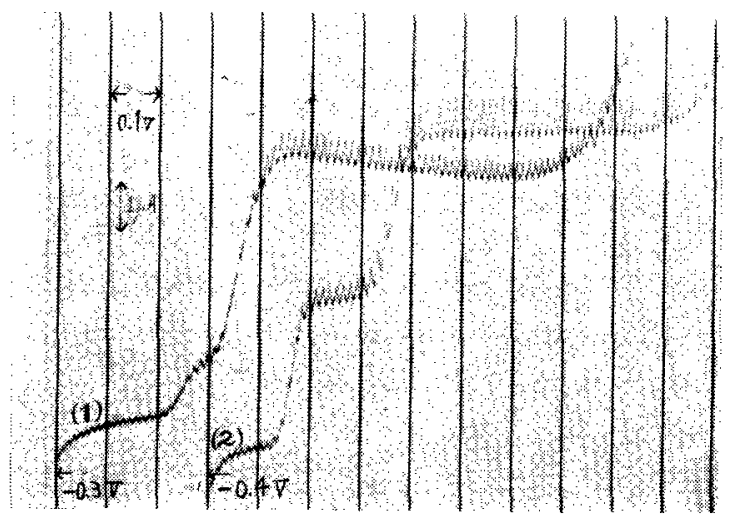

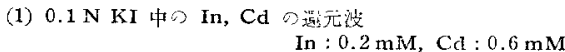

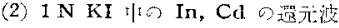

$\mathrm{In}: 0.5 \mathrm{mM}, \mathrm{Cd}: 0.5 \mathrm{mM}$

ゼラチン湍度 $0.01 \%$

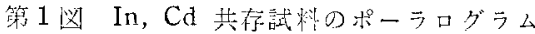

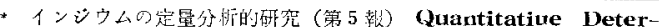
mination of Indiam (Part 5) 昭和29乍 4月 目朴化学公第 年会一講㴼

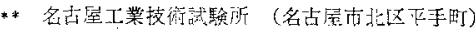

ジョムの半波電位は -0.537 V (v.s. S.C.E.) であり，

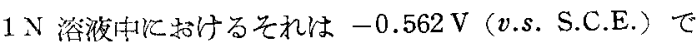

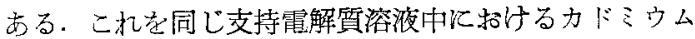
の半波雪位上比較すると，0.1 N ヨードカリ溶液中では 約 $80 \mathrm{mV}, 1 \mathrm{~N}$ ヨードカリ溶液中では約 $180 \mathrm{mV}$ の差が 古る。たがって $1 \mathrm{~N}$ ヨードカり深液中ではインジ ウムとカドミウムの還元波は完全に分﨎する・策 1 図

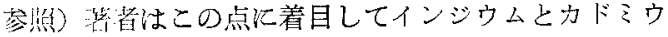

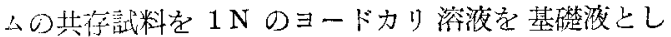
てポーシロダラフ的似電解し，得られたポーラログラ ムの没浮を测定すること炕って，インジウムとカド ミウム嫼相互に分離することなく定㻎しうる可能性を 想し、種々の実験を行なった。その結果について報 化交る。

\section{2. 実験方法とその結果}

ポーラログラフ装置, 試薬などはすべて第 4 報化示 した多の孝使用した。

\section{1.インジウムの拡散電流測定の再現性}

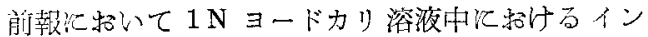

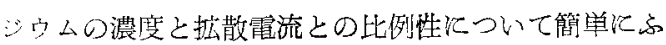

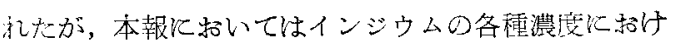

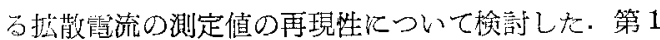

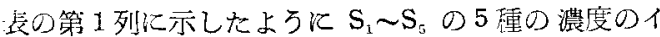


シジウム浴液について应散電流を測定した，毎日 5 種の 濃度の試料溶液を調整し搪散電流を測定し, 10 日飞为た

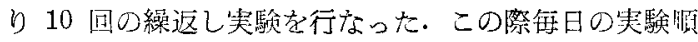

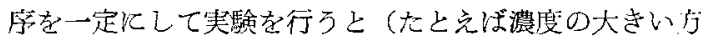

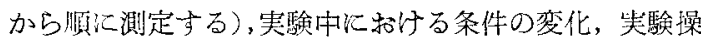
作の熟練の度合などの原因に上り，実験順序のカタョり (Bias) が $\mathrm{S}_{1} \sim \mathrm{S}_{5}$ 間の比較に影響を及保す招それが市

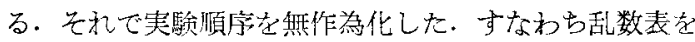

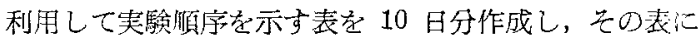
従って每日試料浴液を調整しポーラログラムを記録し， その波高から搪散電流を求めた。1 個の試料汇ついて 回のボーラログラムを記録して，それぞれの拡散笔流值 の平均值をその試料《ついての抁散電流值とした。 また 予㦋実験の結果 $5 \times 10^{-3} \mathrm{~mol} / l$ の試料では，ゼラチン漠 度が $0.015 \%$ 程度でないと極大波を抑制し得ない場合 もあったので、全試料とも $0.015 \%$ で実験を行なった。

その結果を第 1 表江示した. $i d / C$ 江平均 $6.20_{5} \pm 0.025$ でインジウムの拡散電流はその濃度によく比例する。ま た搪散電流晅数は $I=4.76_{2} \pm 0.02_{5}$ であった.

第 1 表 インジウムの搪散電流 $\mathrm{KI} ; 1 \mathrm{~N}$, せテテン $0.015 \% \mathrm{~m}^{2 / 3} \mathrm{t}^{1 / 6}=1.302$

\begin{tabular}{|c|c|c|c|c|c|}
\hline & \multicolumn{5}{|c|}{ 拡 散 電 流 $(\mu \mathrm{A})$} \\
\hline & $\begin{array}{c}S_{1} \\
5 \times 10^{-3} \mathrm{M}\end{array}$ & $\begin{array}{c}S_{2} \\
2 \times 10^{-3} \mathbf{M}\end{array}$ & $\begin{array}{c}S_{3} \\
1 \times 10^{-3} \mathbf{M}\end{array}$ & $\begin{array}{c}S_{4} \\
5 \times 10^{-4} \mathrm{M}\end{array}$ & $\begin{array}{c}S_{5} \\
2 \times 10^{-4} \mathrm{M}\end{array}$ \\
\hline 1 & 30.92 & 12.40 & 6.21 & 3.09 & 1.20 \\
\hline 2 & 31.12 & 12.44 & 6.25 & 3.06 & 1.25 \\
\hline 3 & 31.20 & 12.36 & 6.17 & 3.10 & 1.24 \\
\hline 4 & 31.28 & 12.43 & 6.22 & 3.11 & 1,27 \\
\hline 5 & 31.24 & 12.36 & 6.22 & 3.13 & 1.24 \\
\hline 6 & 31.32 & 12.26 & 6.14 & 3.11 & 1.24 \\
\hline 7 & 30.93 & 12.32 & 6.18 & 3.20 & 1.26 \\
\hline 8 & 31.32 & 12.11 & 6.18 & 3.06 & 1.25 \\
\hline 9 & 31.11 & 12.26 & 6.16 & 3.08 & 1.26 \\
\hline 19 & 30.67 & $11.78^{*}$ & 6.22 & 3.08 & 1.24 \\
\hline 平均 & $31.11_{1}$ & 12.327 & $6.19_{5}$ & $3.10_{2}$ & $1.24_{5}$ \\
\hline$i_{a l} / C$ & 6.22 & 6.16 & 6.20 & 6.21 & 6.22 \\
\hline$i_{d} / C \mathrm{~m}^{2 / 3} \mathrm{t}^{1 / 6}$ & 4.78 & 4.72 & 4.76 & 4.77 & 4.78 \\
\hline
\end{tabular}

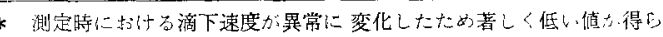
れた，栝定の結果このデータを董てた。

\section{2 インジウム, カトミミウム共存溶液中におけるそ} れぞれの拡散電流と澐度の比例性について

2.2.1 カドミウム蕽度が一定の場合 カに゙ミウム港 度が $1.0 \times 10^{-3} \mathrm{~mol} / l$ のときの各種濃度のインジウム溶 液を調製し，そのポーラログラムを記録し，インジウム の懐度上抎散電流の比例性を検討した。去の結果を第 2 図汇示す，図からかかるように，インジウムの㹡散”流流 と澤度上は，力ドミウムが共存するときに利いても非常 飞よい比例性を示している。

\subsection{2 インジウム濃度が一定の場合 インジウムの} 濃度が $1 \times 10^{-3} \mathrm{~mol} / /$ のときの各種濃度のカドミウム沙 液を調製し，そのポーラログラムからカぼミウムの倯散

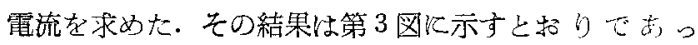

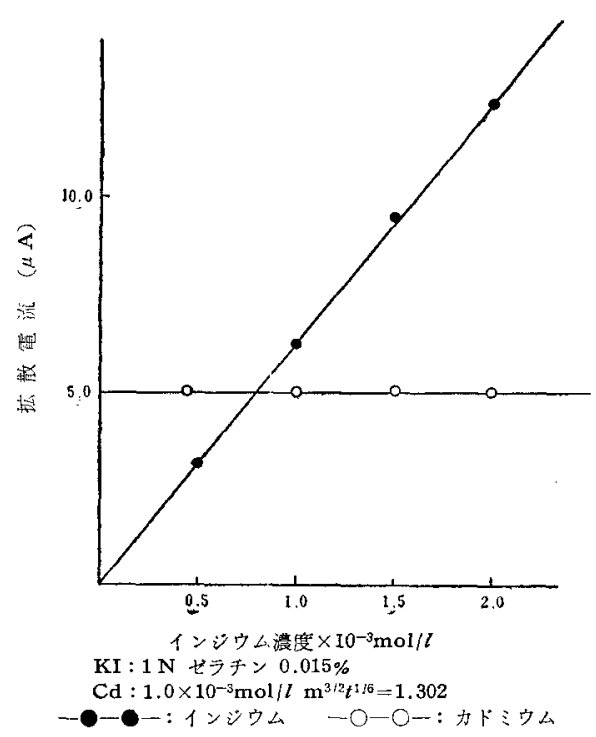

第 2 図インジウムの昖散電流と濃度との 関係

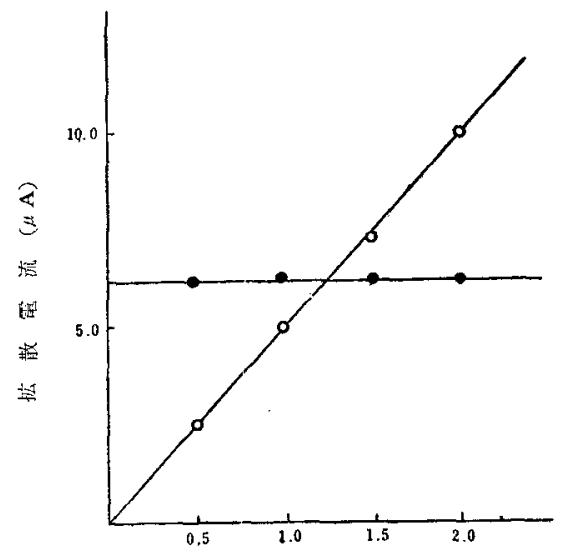

カトミウムの濃度 $\left(\times 10^{-3} \mathrm{~mol} / \mathrm{l}\right)$

$\mathrm{KI}: 1 \mathrm{~N}$ ゼラ゙・ン $0.015 \%$

In : $1.0 \times 10^{-3} \mathrm{~mol} / l, \mathrm{~m} / /^{2 / 3} \mathrm{t}^{1 / 6}=1.302$

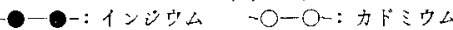

第3図力ドミウムの拡散と濃度との 関经

て，力心゙ミウムの拡散雪流灷その濃度に非常によく比例 する。

\section{3 共存イオンの影響}

\subsection{1 硫酸イオンの影磑 Takagi (2) は塩化力り} または罜酸を支持電解渨としたときのインジウムの還元 波が硫酸イオンの影響杂強くうけることを述へている。 蕃者はヨードカリ存支持電解質としたときのインジウム

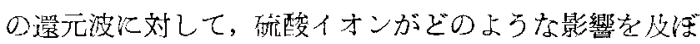

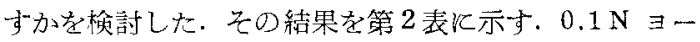
ドカリ溶液の場合林，硫酸イオンの濃度が $1 \times 10^{-2} \mathrm{~mol} / l$ 程度以上飞なると、その影響がかなり明らか炕あらわれ， インジウムの拡散電流は硫酸イオンの濃度が增加するに 
第 2 表 硫酸インンの影響

In $1 \times 10^{-3} \mathrm{~mol} / l$, ぜラ $0.015 \%, \mathrm{~m}^{2 / 3} \mathrm{t}^{1 / 6}=1.302$

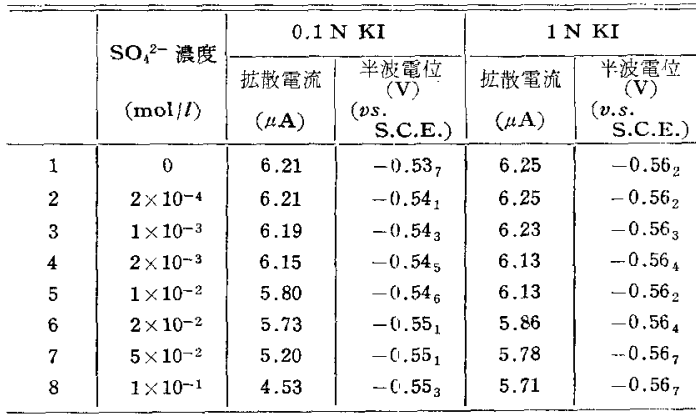

従って減少し,半波電位は次第飞負電位に移行する. $1 \mathrm{~N}$ ヨードカリ溶液の場合にも同じような傾问は見られる が，0.1N 溶液の場合浪ど顕著ではない。

\subsection{2 硝酸イオン，塩素イオンの影響 試料齐鉣}

酸で処理することを考虑して，硝酸イオン，塩素イオン の影響を検討したと結果は第 3 表に示した通りであ って，硝酸イオンの影響は性とんぞ諗められないが，塩 素イオンの影響はわずかで注あるが，拡散電流に対して 子半波電位隹対して子認められる。硫酸イオンの埸合々

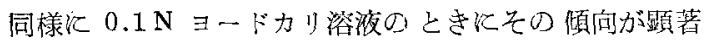
でする。

第 3 食 硝酸イオン, 塩素イオンの影響 In $1 \times 10^{-3} \mathrm{~mol} / l$, ゼラチン $0.015 \% \mathrm{~m}^{2 / 3} \mathrm{t}^{1 / 6}=1.302$

\begin{tabular}{|c|c|c|c|c|c|c|}
\hline & \multirow{2}{*}{$\begin{array}{l}\text { KI } \\
\text { 濃 度 } \\
(\mathrm{N})\end{array}$} & \multirow{2}{*}{$\begin{array}{c}\text { 共存1オン } \\
\text { 濃 度 } \\
(\mathrm{mol} / l)\end{array}$} & \multicolumn{2}{|c|}{ 硝酸’オン } & \multicolumn{2}{|c|}{ 塩港イォン } \\
\hline & & & $\begin{array}{c}\text { 拉散電流 } \\
(\mu \mathrm{A})\end{array}$ & $\begin{array}{c}\text { 半洨雷位 } \\
\text { (v.s. } \\
\text { S.C.E. })\end{array}$ & $\begin{array}{l}\text { 层散電流 } \\
(\mu / \mathrm{A})\end{array}$ & 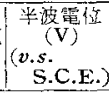 \\
\hline 1 & 0.1 & 0 & 6.19 & $-0.53_{7}$ & 6.15 & $-0.53_{7}$ \\
\hline 2 & " & $2 \times 10^{-4}$ & 6.05 & " & 6.03 & $-0.53_{g}$ \\
\hline 3 & " & $1 \times 10^{-3}$ & 6.01 & $"$ & 5.82 & $-0.54_{0}$ \\
\hline 4 & $\Rightarrow$ & $2 \times 10^{-3}$ & 6.01 & $"$ & 5.67 & $-0.54_{1}$ \\
\hline 5 & " & $1 \times 10^{-2}$ & 6.00 & " & 5.56 & $-0.54_{5}$ \\
\hline 6 & " & $2 \times 10^{-2}$ & 6.00 & " & 5.38 & $-0.54_{6}$ \\
\hline 7 & 1.0 & 0 & 6.25 & $-0.56_{2}$ & 6.25 & $-0.56_{2}$ \\
\hline 8 & $\Rightarrow$ & $2 \times 10^{-4}$ & 6.06 & $-0.56_{3}$ & 6.06 & $-0.56_{3}$ \\
\hline 9 & $\Rightarrow$ & $1 \times 10^{-3}$ & 6.06 & $-0.56_{2}$ & 5.96 & -0.56 \\
\hline 10 & " & $2 \times 10^{-3}$ & 6.06 & $-0.56_{4}$ & 6.00 & $"$ \\
\hline 11 & " & $1 \times 10^{-2}$ & 6.06 & $-0.56_{2}$ & $"$ & $\Rightarrow$ \\
\hline 12 & s & $2 \times 10^{-2}$ & 6.06 & $-0.56_{2}$ & $"$ & $"$ \\
\hline
\end{tabular}

2.3.3 鉄, 錳の影響 インジウムの主原料と目己 れるカドミウム回収経路の鉄沈殿は通常 $10 \%$ 前後の铁 を含有乙，その他のインジウムを含有する試料も多少の 鉄を含えでいるので，鉄イオン共存の影響を検討した。 $\mathrm{Fe}$ (III) が共存しているとヨードカリの微酸性溶液中て

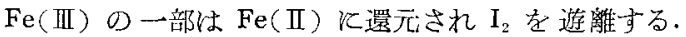
この遊離 $\mathrm{I}_{2}$ は $\mathrm{Fe}$ (III) ととも $-0.37 \mathrm{~V}$ で還元波走示 すので，インジムの還元波そのものには直接影響を与

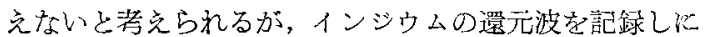
くくなる（前故霆物質の共存）したが。て鉄を分離与る かもしくは Fe(II) に還元して抱人必要がある。そこで
塩酸ヒドロキシルアミンによって鉄を還元した場合に，

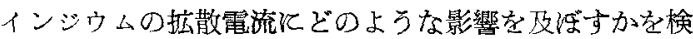
行した、すなわち，インジウム特よび $\mathrm{Fe}(\mathrm{III})$ を合む溶 液に $5 \%$ 塩酸ヒドロキシルアミン溶液を $5 \mathrm{ml}$ 加党, しばらく加温し $\mathrm{Fe}(\mathrm{III}) \rightarrow \mathrm{Fe}$ (II) とする・放泠後ヨード カリ溶液，ゼラチン溶液の適当量を添加して電解液を調 製し，ポーラログラムを記録し，インジウムの拡散電流 を測定し化，その結果は第 4 表《示す通りであって，か なりの量の鉄が共存してる $\mathrm{Fe}$ (II) 飞還元することによ って影響孛除くことができる。

第 4 表 鉄イオン共存の影響

\begin{tabular}{|c|c|c|c|c|c|}
\hline & \multicolumn{5}{|c|}{ インシウウムの拡散筆流（ $\mu \mathrm{A}$ ) } \\
\hline 铁基存量 & $\begin{array}{r}S_{1} \\
5 \times 10^{-3} \mathrm{M} \\
\end{array}$ & $\begin{array}{c}S_{2} \\
2 \times 10^{-3} \mathbf{M} \\
\end{array}$ & $\begin{array}{c}S_{3} \\
1 \times 10^{-3} \mathbf{M} \\
\end{array}$ & $\begin{array}{c}S_{4} \\
0.5 \times \\
10^{-3} \mathrm{M} \\
\end{array}$ & $\begin{array}{c}S_{55} \\
0.2 \times \\
10^{-3} \mathrm{M}\end{array}$ \\
\hline 0 & & 12. & 6.18 & 3.09 & 1.24 \\
\hline 11.1 & 3 & 12 & 6.22 & 3.11 & 1.25 \\
\hline $22.3 \mathrm{mg}$ & 31.11 & 12.38 & 6.21 & 3.08 & 1.20 \\
\hline
\end{tabular}

跺が共存すると過利のヨードイオンにより錯イオンを 形成し，て溚解寸る．この錯イオンは大体 $-0.57 \mathrm{~V}$ (v.s. S.C.E.) 前後で還元されるので，インジウムの還元波と 重蟃波を示してインジウムの定量を好害主る。したがっ

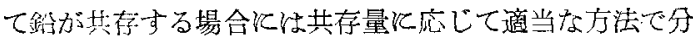
離する必要がある．鉙共存量が比較的少量の場合には， 硫酸路として分離できるが，硫酸イオンの量があまり過 剩にならない上うに注意する必要がある。

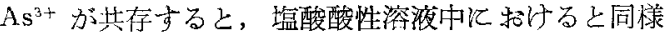
の㕕範围汇方たる還元波を示すので妨害する． $\mathrm{As}^{5+}$ は $1 \mathrm{~N}$ ヨードカり溶液中で還元波を示さない。したが って $\mathrm{As}^{3+}$ が共存するとき山分離するか子 $\mathrm{As}^{5+}$ 酒化し て括く必要がある。

\section{3. 考察}

第 1 表に示した測定值からインジウムの搪散電流測定 に持ける再現性について検討した。すなわち 10 回の絽 返し実駼江よって求めた測定值から，分散怙よびその信 頼限界（信頼度 95\%）を次式招上び $\chi^{2}$ 分布表を利用し て求め扫。

$$
\begin{aligned}
& \sigma^{2}=S /(N-1) \\
& n_{i} \sigma^{2} / x_{1}{ }^{2} \sim n_{i} \sigma^{2} / x_{2}{ }^{2}
\end{aligned}
$$

$$
\text { ここで } \sigma^{2}: \text { 分散 } S: \text { 平方和 }=\sum_{i=1}^{N} x_{i}{ }^{2}-\left(\sum_{i=1}^{N} x_{i}\right)^{2} / N
$$$$
\chi_{1}{ }^{2}, \chi_{2}{ }^{2}: x^{2} \text { 分布表の値 }(97.5 \sim 2.5 \%)
$$

クンジウムの各濃度に和ける分散值とその信頼陏界を 第 4 図に示した．濃度が増加するに従って分散の增加が 諗められ，去の堌加の度合恬 $\mathrm{NH}_{4} \mathrm{Cl}-\mathrm{NH}_{3}$ 溶漼中で銅の 第 2 波老测定したときと非常によく似ている(3)。

つぎにこの行散の值から各䕃度に猢す標濩痛差 $\sigma$, 変㓰䋆数 $\rho=\sigma / \bar{x}_{1} \times 100 \%$ ( $\bar{x}_{1}$ 任平均值) を求め，第 5 表に示した．銅の定量の場合と比較して標準编差も翂動 


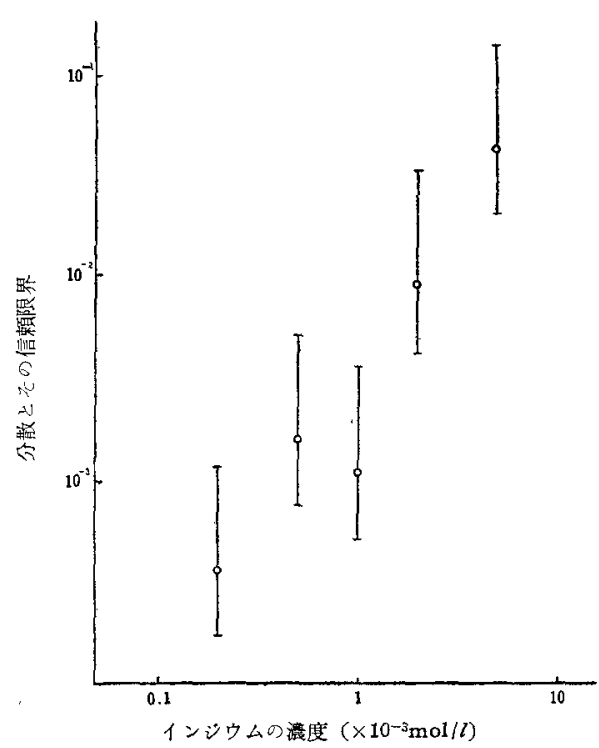

第 4 図 濃度一分散とその信頼限界

第 5 表 搪散電流測定の再現性

\begin{tabular}{|c|c|c|c|c|}
\hline & $\begin{array}{c}\text { In } \sigma \text { 浀度 } \\
\times 10^{-3} \mathrm{~mol} / l\end{array}$ & 分 散 $\left(a^{2}\right)$ & $\begin{array}{c}\text { 標準偏諘 } \\
(0)\end{array}$ & 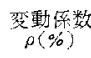 \\
\hline 1 & 5.0 & 0.0442 & 0.210 & 0.68 \\
\hline 2 & 2.0 & 0.0095 & $0.09_{7}$ & 0.79 \\
\hline 3 & 1.0 & 0.0011 & $0.03_{3}$ & 0.53 \\
\hline 4 & 0.5 & 0.0016 & $0.04_{0}$ & 1.29 \\
\hline \multirow[t]{2}{*}{5} & 0.2 & $0.0003_{6}$ & $0.01_{9}$ & 1.61 \\
\hline & $\mid \begin{array}{c}\mathrm{Cu} \text { の澧度 } \\
\times 10^{-3} \mathrm{~mol} / l\end{array}$ & & & \\
\hline 1 & 3.3 & 0.0198 & $0.14_{1}$ & 1.3 \\
\hline 2 & 1.7 & 0.0067 & $0.08_{2}$ & 1.6 \\
\hline 3 & $0.8_{5}$ & 0.0019 & $0.04_{3}$ & 1.6 \\
\hline 4 & $0.3_{3}$ & 0.0011 & $0.03_{6}$ & $3 \cdot 1$ \\
\hline 5 & $0.1_{7}$ & $0.0002_{7}$ & $0.01_{6}$ & 3.1 \\
\hline
\end{tabular}

係数もかなり小さくなっている（参考のため銅の定量の 場合の数值を第 5 表江併記した)。これはインジウムの盼 合，1個の試料についてポーラログラムを3 国記録し，

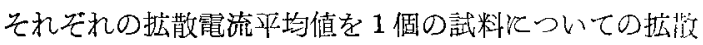
電流值としたことと，銅の場合に窒素ガ入通気などて上 るアンモニア濃度の変化などが原因しているのか子知れ ない。

\section{4. 実試料の分析}

著者はここに示したポーラログラフ法によるインジウ ムとカドミウムの同時定量法の奏試料への適用性老検封 すべく、インジウムの主要原料と目される“カドミウム 回収経路の鉄沈殿”（以下鉄沈殿と略記する）について，
インジウムとカドミウムを定量した.

鉄沈殿約 $0.5 \mathrm{~g}$ を精ひようし $200 \mathrm{ml}$ のビーカーにと り, 王水約 $20 \mathrm{~m} l$ を加光加熱分解する. 不溶解物を口過 し口液を水浴上で蔒発乾固する.塩酸 $(1: 1) 1 \mathrm{ml}$, 水 50 $\mathrm{m} l$ を加光て溶解した後, 硫酸 $(1: 1) 2 \sim 3 \mathrm{ml}$ を加光 共存与る鉛を硫酸鉛として沈殿させロ別する。口液温 酸ヒドロキシルア そンを加え加温し 第 6 表 鉄沈殿中の In, Cd $の$ て $\mathrm{Fe}($ III $) \rightarrow \mathrm{Fe}(\mathrm{II})$ とした後, メスフ ラスコに移し正確 に $100 \mathrm{ml}$ にうす める.この液の一 部にヨードカリ溶

\begin{tabular}{|c|c|c|}
\hline \multirow{2}{*}{ 分 析 法 } & \multicolumn{2}{|c|}{ 定 量 侣 } \\
\hline & $\operatorname{In}(\%)$ & $\operatorname{Cd}(\%)$ \\
\hline ポーラロクラフ法 & $\begin{array}{l}4.5_{T} \\
4.5_{T}\end{array}$ & $\begin{array}{l}28.7 \\
28.6\end{array}$ \\
\hline 化学:分析法 & $\begin{array}{l}4.61 \\
4.62\end{array}$ & $\begin{array}{l}28.78 \\
28.67\end{array}$ \\
\hline
\end{tabular}
液，ゼラチン溶液の適当量を加えて電解液を調製し，ポ 一ラログラムを記録し，その波高からインジウムとカド ミウムの含有量を求めた，濃度の決定にあたって標準体 添加法莡採用した。

その結果を化学分析法によって定量した值ととるに第 6 表沉示した。

\section{5. 総}

括

以上要約すると

1)インジウム，カドミウムの共存試料をヨードカリ 溶液中でポーラログラフ的䉓解し, 得られたポーラロ グラムの波高を测定することによって，インジウム，力 ド々ウムを相互化分離することなく同時定量することが 可能である.

2) 半波電位の差が大きいこと，ゼラチン，その他共 存イオンの影響が少ないことなどから，支持電解質の澱 度恬 $1 \mathrm{~N}$ 溶液が適当である。

3) $1 \mathrm{~N}$ ヨードカリ溶潗に招ける各種濃度のインジウ 么の桩散電流の再現性は非常に良好で $5 \sim 1 \times 10^{-3} \mathrm{~mol} / l$ で 196 以下, $5 \sim 2 \times 10^{-1} \mathrm{~mol} / \mathrm{l}$ では $1.5 \%$ 前後の変動 係数であった.

この砳究を行うにあたって，ご银篤なるご指導を賜わ った恩的京都大学石橋雅義教授に深甚なる感射の意を表

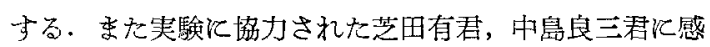
锹或古.

(昭 34-1-5 受珄)

\section{文 献}

1) 松前鼎一: 電化, 27, 549 (1959)

2) S. Takagi : J. Chem. Soc., 1928, 301.

3) 松前鼎一，山下政夫外：名工試報， 6，24（1957） 